\title{
Enhancing the Effects of Zerumbone on THP-1 Cell Activation
}

\author{
Min Ho Lee ${ }^{1}$, Sa Hyun Kim², Sung Ryul Ryu², Pyeongjae Lee ${ }^{3}$, Cheol Moon ${ }^{2}$ \\ ${ }^{1}$ Department of Biomedical Laboratory Science, College of Health Sciences, Yonsei University, Wonju, Korea \\ ${ }^{2}$ Department of Clinical Laboratory Science, Semyung University, Jecheon, Korea \\ ${ }^{3}$ Department of Natural Medicine Resources, Semyung University, Jecheon, Korea
}

\section{단핵구세포주의 활성에 미치는 Zerumbone의 영향}

\author{
이민호 ${ }^{1}$, 김사현 ${ }^{2}$, 유성률 ${ }^{2}$, 이평재 ${ }^{3}$, 문 철 $^{2}$ \\ ${ }^{1}$ 연세대학교 보건과학대학 임상병리학과, ${ }^{2}$ 세명대학교 임상병리학과, ${ }^{3}$ 세명대학교 자연약재학과
}

\begin{abstract}
Zerumbone is a major component of the essential oil from Zingiber zerumbet Smith, which is a kind of wild ginger. In addition, various biological functions, such as liver protection, pain relief, atherosclerosis, and antimicrobial activity have been reported. It is also known to be effective in the proliferation of immune cells and the expression of cytokines. In this study, we investigated the effects of zerumbone on monocyte activation. First, it was confirmed that the proliferation of THP-1 cells was increased by zerumbone. The strongest increase in THP-1 proliferation after lipopolysaccharide treatment was observed at $5 \mu \mathrm{M}$ zerumbone treatment, and the increase of cell proliferation without lipopolysaccharide was the highest at $10 \mu \mathrm{M}$. Conversely, when treated with $50 \mu \mathrm{M}$ zerumbone, a rapid decrease of proliferation was observed regardless of the presence of lipopolysaccharide (LPS). The phosphorylation of signaling protein, Erk, induced by LPS was also increased by zerumbone. The strongest increase in phosphorylation was observed when treated with $50 \mu \mathrm{M}$ of zerumbone with reduced proliferation. The activity of transcription factor NF- $\kappa \mathrm{B}$ was not significantly altered by zerumbone alone, but increased when treated with lipopolysaccharide. Furthermore, the transcription of the inflammatory cytokines TNF- $\alpha$ and IL-8, which are regulated by NF- $\mathrm{KB}$, is also increased by zerumbone. These results suggest that zerumbone can enhance the proliferation and activity of monocytes. Furthermore, it is believed that zerumbone can enhance rthe immune responses through increased monocyte activity in bacterial infections with LPS, thereby helping to treat effective bacteria.
\end{abstract}

Key words: Zerumbone, Monocyte, Lipopolysaccharide

This is an Open Access article distributed under the terms of the Creative Commons Attribution Non-Commercial License (http://creativecommons.org/licenses/by-nc/4.0) which permits unrestricted non-commercial use, distribution, and reproduction in any medium, provided the original work is properly cited.

Copyright (C 2017 The Korean Society for Clinical Laboratory Science. All rights reserved.
Corresponding author: Cheol Moon Department of Clinical Laboratory Science, Semyung University, 65 Semyung-ro, Jecheon 27136, Korea

Tel: 82-43-649-1419

Fax: 82-43-649-1537

E-mail: antigene@semyung.ac.kr

Received: January 5, 2017

Revised $1^{\text {st. }}$ January 25, 2017

Revised 2 ${ }^{\text {nd }}$ : January 26, 2017

Accepted: January 26, 2017

\section{서 론}

Zerumbone은 야생 생강의 일종인 Zingiber zerumbet Smith의 정유(essential oil)에 포함되어 있는 주요성분으로, 다 양한 연구를 통해 혈액종양을 포함한 암, 염증질환, 활성산소감 소 등에 이용할 가능성이 꾸준히 제기되어왔다[1-3]. 또한 면역
세포들의 증식과 세포주기진행, 사이토카인의 생성 - 발현에도 효과를 나타낸다고 알려져 있다[4]. 이외에도 간보호, 통증완 화, 항동맥경화, 항미생물 등 다양한 생물학적 기능이 보고되었 다[5-8]. Zerumbone의 효능 중 항암효과에 대한 연구는 가장 활발히 진행되고 있는 분야다. Zerumbone은 암세포의 증식, 생존, 혈관형성을 억제하는 기능이 있음이 보고되었는데, 이 연 
구는 신장상피세포암 세포주를 이용하여 이종이식 모델을 통해 진행되었다. 이와같은 zerumbone의 항암 효능은 STAT3의 활 성을 저하시킴으로써 발휘된다고 보고되었다[9]. 또한, zerumbone은 이자 상피암의 암세포 자가사멸을 유도한다고 도 보고되었는데, 이 경우에는 $\mathrm{p} 53$ 신호전달 체계의 활성화 시 켜 자가사멸을 유도한다고 알려졌다[10]. 이외에도 간암, 위암, 피부암, 담도암 등 다양한 암세포의 세포자멸사 유발, 전이 방지 효능을 지닌 것으로 알려져 있다. 아울러, 항염증 효능도 다양한 연구에 의해 보고되었다. Zerumbone 식이를 통해 dextran sodium sulfate (DSS) 유발 급성궤양성장염 증세가 호전되었으 며[11], 콜라겐 유발 관절염 모델 렛트에게 zerumbone 화합물 을 먹인 경우 증세가 호전되었다는 보고도 있다[12]. Zerumbone의 면역조절 기능 역시 보고되었다. Mouse의 흥선 세포와 비장세포의 증식이 zerumbone에 의해 더욱 강화되었 으며, 사람 말초혈액 단핵세포(peripheral blood mononuclear cell, PBMC)의 증식 역시 zerumbone에 의해 증가됨이 보고되었다. 또한, zerumbone이 G2/M 세포주기 집중현상, 그 리고, interleukin (IL)-2, IL-12 생성/분비 증가를 유발함이 보 고되었다[4]. 아울러, SDF-1 $\alpha$ 에 의해 유도된 T세포주 Jurkat cell의 유주현상이 zerumbone에 의해 억제됨도 보고되었다 [13].

단핵구는 골수에서 생성되는 혈구로써 선천면역계를 구성하 는 주요 세포다. 혈액을 따라 신체를 순환하며 탐식 기능 수행 뿐 아니라, 조직으로 이동한 후에는 다양한 대식세포 혹은 가지상 세포로 분화하여 조직에 침투한 외부 감염 인자 탐식, 조직 항상 성 유지 등의 기능을 발휘한다. 가지상세포는 외부 인자 탐식 후 $\mathrm{T}$ 림프구에게 항원을 제시하여 선천면역과 후천면역의 매개자 로써의 역할을 수행한다. 그러므로, 단핵구의 활성과 기능에 대 한 지식은 면역반응 전체를 이해하는 중요한 시작점이 된다. 나 아가 단핵구의 활성과 기능을 강화 혹은 제어할 수 있는 기전을 통해 외부 침입 인자에 대한 방어를 강화하거나 면역반응을 조절 할 수 있을 것으로 여겨진다.

본 연구는 염증반응, 암세포를 비롯한 면역세포에 다양한 기 능을 나타내는 zerumbone이 단핵구의 활성과 기능에 어떠한 영향을 미치는지 알아보고자 하는 목적으로 진행되었다. 먼저 단핵구세포주 THP-1세포의 활성이 zerumbone에 의해 증가 되는 것을 확인하였으며, LPS에 의해 유도되는 신호전달 단백 질 Erk의 인산화와 전사인자 NF-KB의 활성 또한 zerumbone 에 의해 증가되는 것을 관찰하였다. 나아가, NF- $\mathrm{kB}$ 에 의해 발현 이 조절되는 염증 사이토카인 TNF- $\alpha$, IL-8의 전사도 zerumbone이 증가시키는 것을 확인하였다. 이와 같은 결과를
통해 zerumbone이 lipopolysaccharide (LPS) 에 의한 단핵구 활 성을 더욱 강화시킬 수 있음을 확인하였다.

\section{재료 및 방법}

\section{1. 시약}

본 연구에서 사용된 시약은 Zerumbone (Sigma-Aldrich, St. Louis, MO, USA)와 Lipopolysaccharide (LPS, SigmaAldrich, St. Louis, MO, USA)이다.

\section{2. 세포 및 세포배양}

사용한 세포는 사람 단핵구세포주인 THP-1세포(Korean Cell Line Bank, Seoul, Korea)이다. 세포배양액은 Roswell Park Memorial Institute (RPMI) 1640 medium with L-glutamine (Lonza, Walkersvill, MD, USA)에 10\% (v/v) Fetal bovine serum (FBS) (Gibco, Grand Island, NY, USA), 1\% (v/v) Penicillin/Streptomycin (Gibco, Grand Island, NY, USA), 1\% (v/v) 4-(2-hydroxyethyl)-1-piperazineethanesulfonic acid (HEPES) (Welgene, Daegu, Korea), 1\% (v/v) non-essential amino acid (Welgene, Daegu, Korea)를 첨가하여 사용하였다. 배양은 $37^{\circ} \mathrm{C}, 5 \% \mathrm{CO}_{2}$ 조건을 맞춘 배양기를 이용하여 진행하 였다.

\section{Cell viability assay}

세포증식 측정은 WST assay kit인 EZ-CYTOX (Daeillab, Seoul, Korea)를 이용하여 시행하였다. 업체에서 제공한 사 용법을 일부 변경하여 진행하였다. $2 \times 10^{4}$ 개의 세포를 다양 한 농도 $(0,1 \mu \mathrm{M}, 5 \mu \mathrm{M}, 10 \mu \mathrm{M}, 50 \mu \mathrm{M})$ 의 zerumbone과 함 께 $200 \mu \mathrm{L}$ 배양액에 넣어 96 well plate에 분주하였다. $37^{\circ} \mathrm{C}$, $5 \% \mathrm{CO}_{2}$ 조건에서 24 시간 배양 후, Ez-CYTOX 시약 $10 \mu \mathrm{L}$ 을 각 well에 첨가하였다. 4 시간의 추가 배양 후 마이크로플레 이트 리더 Sunrise (Tecan, Männedorf, Switzerland)를 이 용하여 $450 \mathrm{~nm}$ 에서 흡광도를 측정하였다.

\section{Western blot을 통한 단백질양 및 인산화정도 분석}

THP-1 세포주를 $60 \mathrm{~mm}$ 배양 접시에 $2 \times 10^{6}$ cells/well로 seeding 후 LPS를 $1 \mu \mathrm{g} / \mathrm{mL}$ 농도로, zerumbone을 다양한 농도 $(1,5,10,50 \mu \mathrm{M})$ 로 12 시간 동안 처리해 주었다. PBS로 2회 세 척한 후 lysis buffer를 이용해 세포를 용해시키고 $19,000 \times \mathrm{g}$, $4^{\circ} \mathrm{C}$ 에서 10 분간 원심분리하여 단백질을 추출하였다. 단백질의 농도는 Lowry protein assay kit (Bio-Rad, Hercules, CA, 
$\mathrm{USA}$ )를 이용해 정량하였고, $30 \mu \mathrm{g}$ 의 단백질을 $10 \%$ acrylamide gel에서 전기영동하여 분리하였다. 분리된 단백질은 nitrocellulose membrane에 transfer하고 5\% skim milk를 이 용해 실온에서 1 시간 blocking 후 각각 pErk1/2, Erk, IkBa, $\beta$-actin에 특이적인 1 차 항체를 희석하여 $4^{\circ} \mathrm{C}$ 에서 overnight 동안 반응시켰다. 1 차 항체와 반응이 끝나면 3회 세척 후 2차 항 체와 실온에서 2 시간동안 반응 시키고, 다시 3회 세척한 후 $\mathrm{ECL}$ kit (Thermo, Waltham, MA, USA)와 반응시켜 X-ray film을 이용해 단백질의 양 및 인산화 정도를 측정하였다.

\section{Reverse transcription-polymerase chain reaction (RT-PCR)을 이용한 사이토카인 발현 분석}

THP-1 세포주를 6-well plate에 $1 \times 10^{6}$ cells/well로 seeding 후 LPS를 $1 \mu \mathrm{g} / \mathrm{mL}$ 농도로, zerumbone을 $10 \mu \mathrm{M}$ 농 도로 3 시간 동안 처리해 주었다. 세포를 PBS로 2 회 세척한 후 NucleoZOL (Macherey-Nagel, Düren, Germany)을 이용하 여 RNA를 추출하였다. 추출한 RNA $2 \mathrm{ng}$ 을 random hexamer $0.25 \mathrm{ng}, \mathrm{dNTP} 10 \mathrm{nmole}$ 과 $65^{\circ} \mathrm{C}$ 에서 5 분간 반응시킨 후 $5 \times$ buffer $4 \mathrm{~mL}$, DTT 200 mmole, MMLV-RT 200 unit을 첨가하 여 $25^{\circ} \mathrm{C}$ 에서 10 분, $37^{\circ} \mathrm{C}$ 에서 50 분, $70^{\circ} \mathrm{C}$ 에서 15 분간 반응하 여 $\mathrm{CDNA}$ 를 합성하였다. 합성한 $\mathrm{CDNA}$ 를 이용해 $\mathrm{IL}-8, \mathrm{TNF}-\alpha$ 특이적인 primer를 제작하여 PCR을 수행하였다. Primer에 대 한 정보 및 PCR 수행 조건은 Table 1에 요약하였다.

\section{6. 통계분석}

실험결과는 mean $\pm \mathrm{SD}$ 로 표현하였다. $\mathrm{ANOVA}$ 를 이용한 Student t-test를 통해 $p<0.05$ 이하인 경우를 유의한 것으로 판정하였다.

\section{결 과}

\section{Zerumbone에 의한 THP-1 세포 활성 변화}

단핵구 세포주인 THP-1 세포 단독 혹은 LPS $(1 \mu \mathrm{g} / \mathrm{mL})$ 로 처 리한 후, 다양한 농도의 zerumbone $(0,1 \mu \mathrm{M}, 5 \mathrm{nM}, 10 \mu \mathrm{M}, 50$ $\mu \mathrm{M})$ 과 함께 24 시간 배양했다. 이후 WST assay를 통해 세포 증
식 변화를 측정하였다(Figure 1). LPS 없이 zerumbone만 처리 했을 경우, THP-1 세포의 활성은 zerumbone의 농도에 비례하 여 증가하였다. 이러한 활성 증가는 $1 \mu \mathrm{M}$ 의 zerumbone 처리 후부터 관찰되어, $10 \mu \mathrm{M}$ 의 zerumbone을 처리했을 때 가장 높 게 나타났다. 그러나, $50 \mu \mathrm{M}$ 농도에서는 zerumbone을 처리 하 지 않은 조건과 비슷한 정도로 활성이 감소되었다. LPS (1 $\mu \mathrm{g} / \mathrm{mL}$ )를 처리한 경우에도 유사한 경향의 THP-1 세포 활성 증 가가 관찰되었다. LPS만을 처리해 주었을 때 THP-1 세포 활성 은 $50 \%$ 이상 증가하는데, 이와 같은 세포 활성의 증가는 zerumbone에 의해 더욱 가중되었다. $5 \mu \mathrm{M}$ 의 zerumbone을 처리해 준 조건에서 LPS에 의한 세포 활성이 가장 증가한 것을 관찰하였다. $10 \mu \mathrm{M}$ 의 zerumbone 농도부터는 활성이 감소하 기 시작하여 $50 \mu \mathrm{M}$ 에서는 LPS 단독 처리 조건 보다 활성이 감 소되었다.

\section{Zerumbone에 의한 Erk 단백질의 인산화 변화와 $\mathrm{NF}-\mathrm{kB}$ 의 활성 변화}

Zerumbone 처리 후 주요 신호전달 단백질인 Erk의 인산화 정도를 western blot을 통하여 살펴 보았다(Figure 2). Erk 단

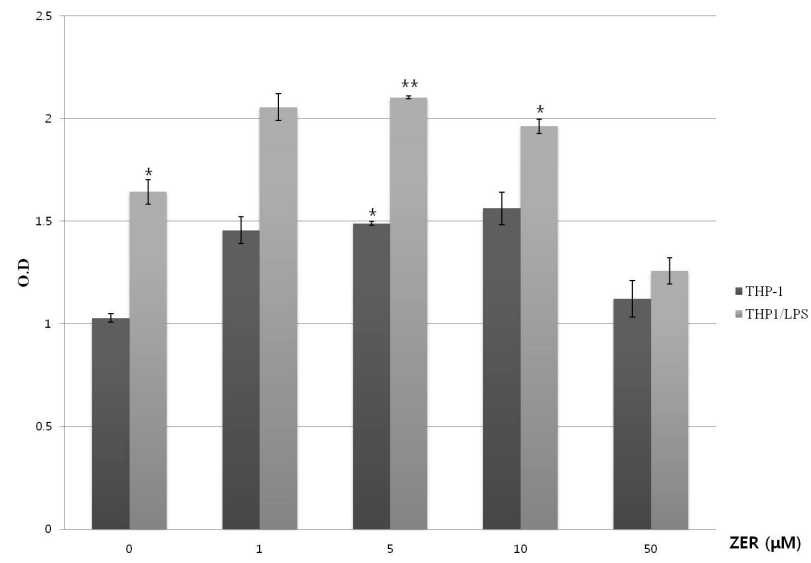

Figure 1. Effects of zerumbone on proliferation of THP-1 cells. THP-1 cells are incubated with (light grey bar graph) or without (dark grey bar graph) LPS $(1 \mu \mathrm{g} / \mathrm{mL})$ for $24 \mathrm{hr}$. Various concentrations of zerumbone were added to the culture. After 24 hr of incubation, WST assay was performed measuring the absorption of light at $450 \mathrm{~nm}$ wave-length. Values present mean \pm SD of three separate experiments $\left({ }^{\star} p<0.05,{ }^{* \star} p<0.01\right)$.

Table 1. List of primer sequences and conditions used for RT-PCR

\begin{tabular}{|c|c|c|c|c|c|}
\hline \multirow{2}{*}{ Primers } & \multicolumn{2}{|c|}{ Sequences $\left(5^{\prime}-3^{\prime}\right)$} & \multirow{2}{*}{$\begin{array}{l}\text { Product } \\
\text { length (bp) }\end{array}$} & \multirow{2}{*}{$\begin{array}{c}\text { Annealing } \\
\text { temperature }\left({ }^{\circ} \mathrm{C}\right)\end{array}$} & \multirow{2}{*}{ Cycles } \\
\hline & Forward & Reverse & & & \\
\hline TNF- $\alpha$ & AGCCCATGTTGTAGCAAACC & CTGAGTCGGTCACCCTTCTC & 360 & 67 & 31 \\
\hline IL8 & ATGACTTCCAAGCTGGCCGTGGCT & TCTCAGCCCTCTTCAAAAACTTCTC & 289 & 62 & 23 \\
\hline GAPDH & CGGGAAGCTTGTCATCAATGG & GGCAGTGATGGCATGGACTG & 349 & 55 & 21 \\
\hline
\end{tabular}


백질의 인산화는 $50 \mu \mathrm{M}$ 의 zerumbone 단독 처리 시 관찰되었 으나, $1,5,10 \mu \mathrm{M}$ 농도의 zerumbone 처리 시에는 거의 관찰 되 지 않았다. LPS를 처리했을 경우에는 Erk의 인산화가 증가하였 고, 이러한 현상은 zerumbone 첨가에 따라 더욱 강하게 발생하 였다. 첨가해 준 zerumbone의 농도가 증가할수록 Erk의 인산 화는 증가했으며, $50 \mu \mathrm{M}$ 의 농도에서 가장 강한 인산화가 관찰 되었다. 다음으로, 주요 전사인자인 NF- $\kappa \mathrm{B}$ 의 활성을 제어하는 $\mathrm{I} \kappa \mathrm{B} \alpha$ 의 발현 변화를 살펴보았다. Zerumbone 단독 처리 시, 50

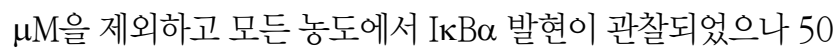

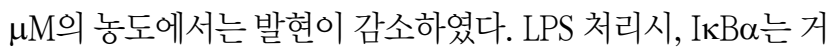
의 완전히 사라졌으며 zerumbone 추가 처리 시에도 변화가 없 었다.

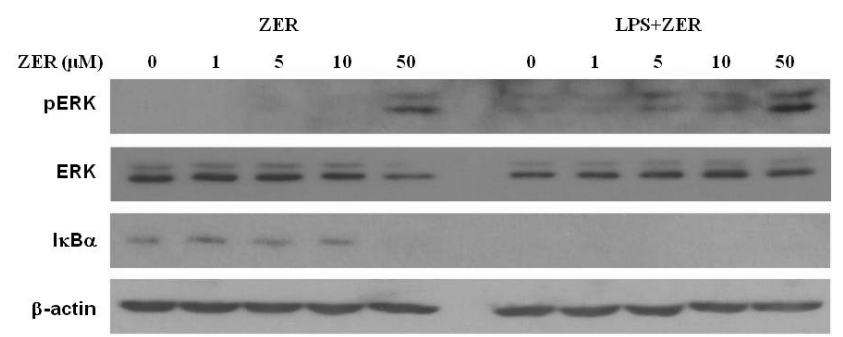

Figure 2. Changes in signal transduction proteins after zerumbone treatment. Changes in the phosphorylation patterns of Erk proteins and changes in transcription factor NF- $\mathrm{NB}$ activity after zerumbone treatment were analyzed. Phosphorylation of Erk was increased by zerumbone, and phosphorylation was further increased when LPS and zerumbone were simultaneously treated. After zerumbone treatment, the expression of $\mid \kappa B \alpha$, which inhibits the activity of $\mathrm{NF}-\kappa \mathrm{B}$, decreased.

\section{Zerumbone에 의한 TNF- $\alpha, \mathrm{IL}-8$ 의 발현 변화}

주요 염증관련 싸이토카인인 TNF- $\alpha$, IL-8의 발현이 zerumbone에 의해 변화되는 패턴을 RT-PCR 기법을 이용하여 관찰 하였다(Figure 3A). LPS 단독 처리 3시간 후 TNF- $\alpha$, IL-8의 전 사가 증가하였고, LPS와 함께 zerumbone을 동시에 처리하였 을 경우 두 사이토카인의 전사는 더욱 증가하여 LPS 단독 처리 조건에 비해 TNF- $\alpha$ 는 약 3 배, IL-8은 약 2 배의 전사 증가를 나 타냈다. 이와 같은 전사의 증가는 $\mathrm{PCR}$ 결과(Figure $3 \mathrm{~A}$ )와 $\mathrm{GAPDH}$ 유전자 전사에 대한 상대적 증가를 그래프로 나타냈을 때 확인할 수 있다(Figure 3B).

\section{고 찰}

본 연구는 야생 생강의 일종인 Zingiber zerumbet Smith의 주요 생물 활성 성분인 zerumbone이 단핵구의 기능에 미치는 영향을 알아보고자 진행되었다. 실험에 사용된 THP-1 세포는 급성 단핵구성 백혈병 세포에서 유래한 세포주로써 단핵구의 기능, 기능 기전, 신호전달과정, 단핵구 및 대식세포 기능 등 다 양한 단핵구 관련 연구에 널리 사용되고 있다[14]. 시험관에서 THP-1 세포는 LPS 단독 혹은 여러 염증 유발 사이토카인 등에 의해 활성화 된다[15]. 본 연구진도 LPS를 통해 THP-1 세포의 활 성을 유도하며 zerumbone의 영향을 평가했다. $1 \mu \mathrm{g} / \mathrm{mL} \mathrm{LPS}$ 를 처리하거나 처리하지 않은 세포에 $1,5,10,50 \mu \mathrm{M}$ 의 zerumbone을 첨가하고 24시간 후 세포의 활성을 WST assay 로 분석하였다. Zerumbone만 처리한 세포들은 활성이 증가하 였으며, zerumbone의 농도가 증가할수록 활성은 더욱 증가하
(A)

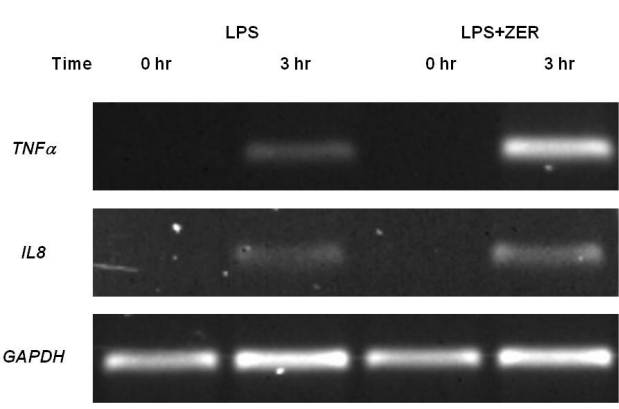

(B)

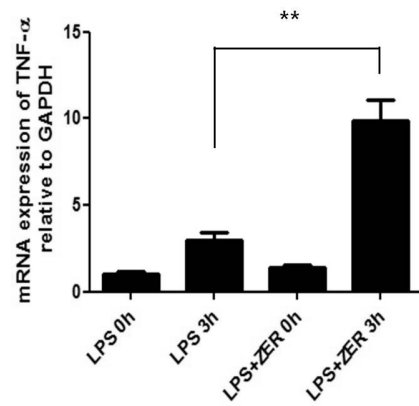

$p=0.004$

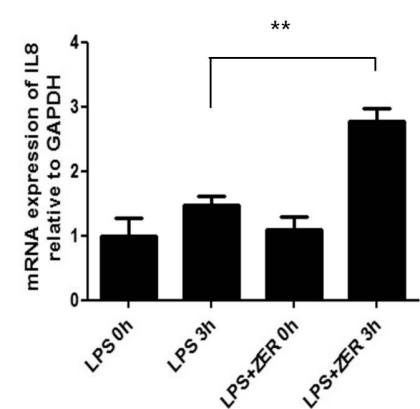

$p=0.006$

Figure 3. (A) Effects of zerumbone on the transcription of inflammatory cytokines. After the THP-1 cell line was treated with LPS and zerumbone, mRNA was obtained and RT-PCR was performed. Transcription of TNF- $\alpha$ and IL-8 was increased during LPS treatment, and transcription of two cytokines was further increased when LPS and zerumbone were simultaneously treated. (B) A graph of the standardization of the transcription of cytokines induced by zerumbone. Zerumbone increased the amount of TNF- $\alpha$ by about 3-fold and the amount of IL-8 by about 2 -fold. Values present mean \pm SD of three separate experiments $\left({ }^{\star} p<0.05,{ }^{* *} p<0.01\right)$. 
였다. $10 \mu \mathrm{M}$ 의 zerumbone을 처리해 주었을 때 가장 높은 활성 증가를 나타냈으나, $50 \mu \mathrm{M}$ 의 zerumbone 처리를 해주었을 경 우에는 활성이 zerumbone을 처리하지 않은 경우와 비슷한 수 준으로 감소하였다. 이러한 zerumbone에 의한 THP-1 세포의 활성 증가, 감소 패턴은 LPS를 처리해 주었을 때도 비슷하게 나 타났다. LPS만 처리해 주었을 때 세포의 활성은 50\% 이상 증가 하였다. 이와 비슷한 정도의 활성 증가는 농도에 따른 zerumbone 처리 시 에도 관찰되다가 $10 \mu \mathrm{M}$ 부터 다소 감소하 여 $50 \mu \mathrm{M}$ 농도에서는 LPS를 처리하지 않은 조건과 비슷하게 감 소하였다. 이와 같은 결과를 통해 zerumbone은 THP-1 세포의 활성을 증가시키며, 이와 같은 기능은 LPS를 처리해 준 상황에 서도 분명하게 나타남을 알 수 있었다. 그러나, $50 \mu \mathrm{M}$ 농도에서 는 LPS 처리, 비처리 조건 모두에서 세포 활성이 확연히 감소하 였다. 이는 zerumbone에 의한 세포독성이 나타난 것으로 보여 진다. Abdelwahab 등[16]은 $8.4 \mu \mathrm{g} / \mathrm{mL}$ zerumbone을 사용하 여 급성T세포백혈병 세포의 세포자멸사(apoptosis)를 유발시 켰다. 이들이 사용한 zerumbone 양을 몰단위로 환산할 경우 약 $38 \mu \mathrm{M}$ 이다. 그러므로, $50 \mu \mathrm{M}$ 의 zerumbone이 세포 독성을 나 타냈을 가능성은 매우 높다. 추후에 세포독성이 발생하는 정확 한 zerumbone의 양을 알기 위해 $10 \mu \mathrm{M}$ 과 $50 \mu \mathrm{M}$ 사이의 여러 농도에서 발생하는 zerumbone의 세포 독성을 더 자세히 살펴 볼 필요가 있다.

다음으로, zerumbone에 의한 세포 내 신호전달 단백질과 전 사인자의 발현 변화를 western blot 기법을 이용하여 분석하였 다. 대표적인 LPS 유발 THP-1 신호전달 단백질 Erk의 인산화 경향 변화를 살펴보았다[17]. 우선, zerumbone만 처리해 주었 을 때, $5 \mu \mathrm{M}$ 농도 조건부터 약하게 $\mathrm{Erk}$ 의 인산화가 관찰되기 시 작하여 농도가 증가하면서 인산화가 증가하는 것을 관찰하였다. LPS와 zerumbone을 함께 처리해 주었을 때도 비슷한 인산화 증 가 경향이 나타났다. Zerumbone 없이 LPS 단독으로 처리했을 때 이미 Erk 인산화가 관찰되며, zerumbone 농도가 증가함에 따라 인산화 정도는 증가하였다. 흥미로운 것은 세포독성이 발 생한 농도인 $50 \mu \mathrm{M}$ 에서 $\mathrm{ERK}$ 의 인산화가 가장 증가했다는 점 이다. 이같은 현상은 zerumbone 단독 처리 시, LPS/zerumbone 처리 시 모두 나타났다. 또한, zerumbone $50 \mu \mathrm{M}$ 만을 처 리해 준 조건에서는 Erk 단백질 자체의 양도 감소한 것으로 관 찰되었다. $\beta$-actin의 양 변화가 없는 것으로 미루어 세포독성으 로 인한 세포량 감소에 따른 Erk 감소로 보기는 어려울 것 같다. 차후 이 현상에 대한 추가적인 연구가 필요할 것으로 보인다. LPS와 zerumbone $50 \mu \mathrm{M}$ 을 동시에 처리해 준 조건에서도 Erk 의 인산화는 가장 증가했다. Zerumbone 만을 처리해 준 조건
보다 더 강한 인산화 증가를 나타냈고 Erk 단백질 감소 현상은 상대적으로 낮게 나타났다. Zerumbone 처리에 의한 Erk 인산 화 증가 현상은 앞서 WST assay를 통해 관찰한 THP-1 세포 활 성 증가와 연관이 있는 듯 여겨진다. 그러나, 세포독성이 발생한 상대적 고농도 zerumbone 처리에 의해 유발된 Erk 인산화 증 가와 세포독성과의 연관성은 추가로 연구되어야 할 과제로 생 각된다. 이어서, 염증 관련 세포 활성에 밀접한 연관이 있는 것 으로 알려진 NF-kB의 활성이[18] zerumbone에 의해 어떠한 영향을 받는지 살펴보았다. NF- $\kappa \mathrm{B}$ 는 평소 $\mathrm{I} \mathrm{KB} \alpha$ 와 결합되어 비 활성 형태로 존재하다가 활성 신호가 전달될 경우 $\mathrm{I \kappa B} \alpha$ 는 떨어 져 나가고 자유로워진 NF-kB는 세포핵 내로 이동하여 활성을 나타낸다. $\mathrm{IkB \alpha}$ 의 양은 $\mathrm{NF}-\kappa \mathrm{B}$ 의 활성과 반비례한다[18]. I $\kappa \alpha \alpha$ 의 발현은 zerumbone 단독 처리에 의해서 별 영향을 받지 않는 것으로 보여진다. 그러나, 세포 독성을 나타낸 $50 \mu \mathrm{M}$ zerumbone은 I $\kappa \mathrm{B} \alpha$ 발현을 거의 모두 감소시켰다. 이와 함께, LPS의 처리도 I $\mathrm{I} B \alpha$ 발현을 감소시켰다. LPS와 zerumbone을 동 시에 처리해주었을 때도 모든 농도에서 I $\mathrm{KB} \alpha$ 발현이 나타나지

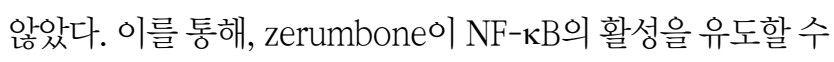
있음을 알 수 있었다. LPS와 zerumbone 모두 처리할 경우에도 $\mathrm{NF}-\kappa \mathrm{B}$ 활성이 유발될 수 있지만, LPS 단독 처리 시에도 I $\kappa \mathrm{B} \alpha$ 감소가 나타나는 것으로 미루어 zerumbone이 LPS에 의한 $\mathrm{NF}-\kappa \mathrm{B}$ 의 활성을 더욱 강화시키는지 여부는 NF- $\kappa \mathrm{B}$ 활성을 측 정하는 다른 실험방법을 통해서 추가로 확인해야 할 것으로 여 겨진다.

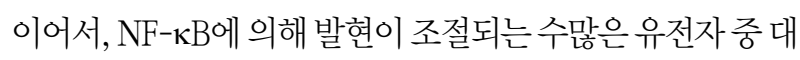
표적인 염증유발 사이토카인인 $\mathrm{TNF}-\alpha$ 와 $\mathrm{IL}-8$ 의 전사가 zerumbone에 의해 영향을 받는지 여부를 분석하였다. 앞선 단 백질 인산화와 전사인자의 발현 분석 실험과 마찬가지로, THP-1 세포를 zerumbone 단독 혹은 LPS와 함께 처리하며 $\mathrm{mRNA}$ 를 얻 은 후 역전사 반응을 통해 $\mathrm{CDNA}$ 를 얻었다. TNF- $\alpha, \mathrm{IL}-8$ 특이 primers를 이용하여 PCR을 시행하였다. 조건 별로 발현된 두 사이토카인의 전사량을 $\mathrm{GAPDH}$ 유전자의 $\mathrm{mRNA}$ 량과 상대적 비교를 통해 표준화하여 정량 하였다. Figure 3의 밴드 사진(A) 과 표준화 그래프(B)에서 확인할 수 있듯이, 두 사이토카인 모두 LPS 처리 시 전사가 증가했다. 특히, LPS와 zerumbone을 동시 에 처리해 주었을 때 전사 증가는 더욱 뚜렷이 나타났다. 반면 에, zerumbone 단독 처리 시에는 전사 증가가 거의 나타나지 않았다. 이 결과를 통해, LPS에 의해 발현되는 대표적인 염증성 사이토카인인 TNF- $\alpha$ 와 IL-8은 zerumbone 추가 처리에 의해 발현이 더욱 증가할 가능성이 크다 할 수 있다. 또한, 두 사이토

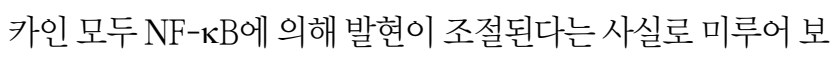


아, LPS가 유도한 NF- $\kappa \mathrm{B}$ 의 활성이 zerumbone에 의해 더욱 증 가했음을 간접적으로 확인할 수 있었다.

본 연구는 zerumbone이 사람 단핵구 세포주인 THP-1 세포 의 활성을 강화할 수 있음을 강하게 시사한다. 전형적인 염증 유 발 인자인 LPS 처리 후 THP-1 세포의 증식이 zerumbone 처리 에 의해 증가되었으며, LPS 신호전달 과정의 주요 신호전달과 정 단백질인 Erk의 인산화 역시 zerumbone에 의해 증가되었 다. 또한, LPS와 zerumbone의 동시 처리를 통해 NF- $\mathrm{KB}$ 의 활 성이 증가하며 연관된 염증성 사이토카인인 TNF- $\alpha$, IL-8 유전 자의 전사가 증가됨을 확인하였다. 이러한 결과처럼, zerumbone에 의한 면역기능 강화를 시사하는 다양한 연구결 과가 보고되었다. 흥선세포와 비장세포의 증식이 zerumbone 에 의해 더욱 강화되었으며, 사람 말초혈액 단핵세포의 증식 역 시 zerumbone에 의해 증가된 보고가 있다. 또한, zerumbone 이 G2/M 세포주기 집중현상, 그리고, IL-2, IL-12 생성/분비 증 가를 유발함도 보고되었다[4]. 이는 zerumbone이 다양한 세포 에 작용하여 면역반응을 증가시킬 수 있는 가능성을 보여주는 결과라 할 수 있다. 단핵구는 침입한 세균에 대한 방어에 참여하 는 주요 탐식세포 중 하나이다. 또한, 세균 탐식 후 대식세포와 가지상세포로 분화하여 보다 효과적인 면역반응을 일으키는 기 능을 수행한다. 이에 본 연구 결과는 zerumbone이 LPS를 보유 한 세균 감염 시 단핵구의 활성을 강화시켜 면역 반응에 도움을 줄수 있음을 보여준다. 향후 이를 확인하기 위해서 단핵구의 탐 식기능, 유주현상, 대식세포로의 분화능력 등이 zerumbone에 의해 어떠한 영향을 받는지 실험적으로 분석해야 할 것으로 보 인다. 또한, 다양한 단핵구의 기능변화 기전을 밝히기 위해 연관 된 사이토카인의 분비 변화를 단백질 수준에서 측정 분석하고, 연관 유전자들의 발현 변화를 분석하는 작업도 아울러 필요할 것으로 여겨진다.

\section{요 약}

Zerumbone은 야생 생강의 일종인 Zingiber zerumbet Smith의 정유(essential oil)에 포함되어 있는 주요성분으로, 다 양한 연구를 통해 혈액종양을 포함한 암, 염증질환, 활성산소 감 소 등에 이용할 가능성이 꾸준히 제기되어왔다. 또한 면역세포 들의 증식과 세포주기진행, 사이토카인의 생성 - 발현에도 효 과를 나타낸다고 알려져 있다. 이외에도 간보호, 통증완화, 항동 맥경화, 항미생물 등 다양한 생물학적 기능이 보고되었다. 본 연 구에서는 zerumbone이 단구의 활성과 기능에 어떠한 영향을 미치는지 알아보고자 하였다. 우선, 단구세포주 THP-1세포의
활성이 zerumbone에 의해 증가되는 것을 확인하였다. LPS 처 리 후 가장 강한 THP-1 증식 증가는 $5 \mu \mathrm{M}$ 의 zerumbone 처리 시 나타났으며, 세포 단독 증식 증가는 $10 \mu \mathrm{M}$ 의 zerumbone 처 리 시 가장 증가하였다. 반면에 $50 \mu \mathrm{M}$ 의 zerumbone 처리 시 에는 LPS 존재 여부와 관계없이 급격한 증식 감소가 관찰되었 다. LPS의 처리에 의해 유도되는 신호전달 단백질 Erk의 인산화 도 zerumbone에 의해 증가되었다. 가장 강한 인산화 증가는 증 식 감소가 나타난 $50 \mu \mathrm{M}$ 의 zerumbone을 처리했을 때 관찰되었 다. 전사인자 NF- $\mathrm{\kappa B}$ 의 활성은 zerumbone 단독 처리 시에는 큰 변화가 없었지만, LPS 와 동시에 처리했을 경우 증가하는 것으로

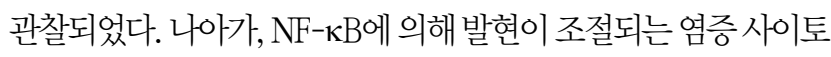
카인 TNF- $\alpha$, IL-8의 전사도 zerumbone 에 의해 증가되는 것을 확인하였다. 이와 같은 결과를 통해 zerumbone이 단핵구의 증식 과 활성을 강화시킬 수 있음을 확인하였다. 나아가, zerumbone이 LPS 를 보유한 세균감염 시 단핵구 활성 증가를 통하여 효과적인 탐식과 면역반응을 강화시켜 효과적인 세균 처리에 도움을 줄수 있을 것으로 여겨진다.

\section{Acknowledgements: None}

Funding: 이 논문은 2014학년도 세명대학교 교내학술연구비 지 원에 의해 수행된 연구임.

Conflict of interest: None

\section{REFERENCES}

1. Murakami A, Ohigashi H. Cancer-preventive anti-oxidants that attenuate free radical generation by inflammatory cells. Biol Chem. 2006;387(4):387-392.

2. Sulaiman MR, Perimal EK, Akhtar MN, Mohamad AS, Khalid MH, Tasrip NA, et al. Anti-inflammatory effect of zerumbone on acute and chronic inflammation models in mice. Fitoterapia. 2010;81(7):855-858.

3. Perimal EK, Akhtar MN, Mohamad AS, Khalid MH, Ming OH, Khalid S, et al. Zerumbone-induced antinociception: involvement of the L-arginine-nitric oxide-cGMP -PKC-K+ ATP channel pathways. Basic Clin Pharmacol Toxico. 2011;1108(3): 155-162.

4. Keong YS, Alitheen NB, Mustafa S, Abdul Aziz S, Abdul Rahman M, Ali AM. Immunomodulatory effects of zerumbone isolated from roots of Zingiber zerumbet. Pak J Pharm Sci. 2010; 23(1):75-82.

5. Kitayama T, Iwabuchi R, Minagawa S, Shiomi F, Cappiello J, Sawada S, et al. Unprecedented olefin-dependent histidinekinase inhibitory of zerumbone ring-opening material. Bioorg Med Chem Lett. 2004;23:5943-5946.

6. Eguchi A, Kaneko Y, Murakami A, Ohigashi H. Zerumbone suppresses phorbol ester-induced expression of multiple scav- 
enger receptor genes in THP-1 human monocytic cells. Biosci Biotechnol Biochem. 2007;71(4):935-945.

7. Sulaiman MR, Perimal EK, Zakaria ZA, Mokhtar F, Akhtar MN, Lajis NH, et al. Preliminary analysis of the antinociceptive activity of zerumbone. Fitoterapia. 2009;80(4):230-232.

8. Taha MM, Abdul AB, Abdullah R, Ibrahim TA, Abdelwahab SI, Mohan S. Potential chemoprevention of diethylnitrosamine- initiated and 2-acetylaminofluorene-promoted hepatocarcinogenesis by zerumbone from the rhizomes of the subtropical ginger (Zingiber zerumbet). Chem Biol Interact. 2010;186(3):295-305.

9. Shanmugam MK, Rajendran P, Li F, Kim C, Sikka S, Siveen KS, et al. Abrogation of STAT3 signaling cascade by zerumbone inhibits proliferation and induces apoptosis in renal cell carcinoma xenograft mouse model. Mol Carcinog. 2015;54(10): 971-985.

10. Zhang S, Liu Q, Liu Y, Oiao H, Liu Y. Zerumbone, a Southeast Asian ginger sesquiterpene, induced apoptosis of pancreatic carcinoma cells through p53 signaling pathway. Evid Based Complement Alternat Med. 2012;2012:936030.

11. Murakami A, Hayashi R, Tanaka T, Kwon KH, Ohigashi H, Safitri R. Suppression of dextran sodium sulfate-induced colitis in mice by zerumbone, a subtropical ginger sesquiterpene, and nimesulide: separately and in combination. Biochem Pharmacol. 2003;66(7):1253-1261.
12. Murakami A, Song M, Katsumata S, Uehara M, Suzuki K, Ohigashi H. Citrus nobiletin suppresses bone loss in ovariectomized ddY mice and collagen-induced arthritis in DBA/1J mice: possible involvement of receptor activator of NF-kappaB ligand (RANKL)-induced osteoclastogenesis regulation. Biofactors. 2007;30(3):179-192.

13. Moon C. Zerumbone's effects on jurkat cell proliferation and migration. Korean J Clin Lab Sci. 2015;47(4):182-187.

14. Chanput W, Mes JJ, Wichers HJ. THP-1 cell line: An in vitro cell model for immune modulation approach. International Immunopharmacology. 2014;23(1):37-45.

15. Chanput W, Mes J, Vreeburg RAM, Savelkoul HFJ, Wichers HJ. Transcription profiles of LPS-stimulated THP-1 monocytes and macrophages: a tool to study inflammation modulating effects of food-derived compounds. Food \& Function. 2010;1(3): 254-261.

16. Abdelwahab SI, Abdul AB, Mohan S, Taha MM, Ibrahim MY, Mariod AA. Zerumbone induces apoptosis in T-acute lymphoblastic leukemia cells. Leuk Res. 2011;35(2):268-271.

17. Guha M, Mackman N. LPS induction of gene expression in human monocytes. Cellular Singnalling. 2001;13:85-94.

18. Lawrence $T$. The nuclear factor NF-kappa $B$ pathway in inflammation. Cold Spring Harb Perspect Bio. 2009;1:a001651. 